\title{
The effect of influenza vaccine immunization on natural antibodies
}

\section{Irena Zivkovic*¹, Lina Muhandes ${ }^{1}$, Vladimir Petrusic ${ }^{1}$, Rajna Minic ${ }^{1}$, Ljiljana Dimitrijevic ${ }^{1}$}

${ }^{1}$ Institute of Virology, Vaccines and Sera - Torlak, 458 Vojvode Stepe, 11000 Belgrade, Serbia

*Corresponding author: Irena Zivkovic, e-mail: izivkovic@torlak.rs

\begin{abstract}
Natural, polyreactive, low-affinity antibodies are known to play an important role not only in the immediate defense against pathogens, but also in shaping the acquired immune response. On the other hand, antigen specific, high-affinity antibodies can affect the balance of natural antibodies and lead to autoimmune diseases. In this study we have analyzed the changes that occur in the IgM and IgG pool of natural antibodies after immunization with split or whole virion influenza vaccine. For this purpose, "in-house" developed ELISAs were used. The subjects were divided, according to the vaccination status, into those who had been immunized with the influenza vaccine in previous years and those who had been immunized for the first time. The analysis indicated that the pool of natural antibodies was not impaired by the immunization, evidenced by the lack of changes in any of the groups, and that certain fluctuations were induced in order to maintain the homeostasis of the immune system.
\end{abstract}

Key words: natural antibodies, immunization, immune homeostasis

doi.org/10.5937/arhfarm71-31544 


\section{Introduction}

It is well known that acquired immunity and the existence of high-affinity antibodies plays a fundamental role in the successful defense of the organism from pathogens. But before the encounter with acquired immunity, the intruders first meet the innate immune system of which natural antibodies (NAbs) are an important component (1). The presence of "natural autoantibodies" in healthy individuals was demonstrated by Besredka approximately 100 years ago (2). Since then, the role of these antibodies in the body's defense against pathogens, the method of isolation (cold alcohol fractionation from pooled plasma from 3000-10,000 healthy blood donors, additional precipitation procedures to remove the non-immunoglobulin $G$ proteins and ion exchange chromatography to further separate out IgGs (3)) and the use as therapy have been established (4). However, many issues remain unclear, including the interaction / dependence of natural and induced antibodies, which may be important for planning new vaccines and immunization methods.

NAbs are immunoglobulins, mainly of the IgM, IgG and IgA (5) classes and function as part of the innate immune system present in healthy individuals, including virtually all vertebrate species. These antibodies are germline determined, polyreactive, usually with low affinity and can recognize both endogenous and foreign antigens. An individual's natural antibody pool is formed early in the ontogeny and stays constant within a 20 -year interval $(6,7)$, while induced antibodies become heterogeneous over time (8).

Natural $\operatorname{IgM}(\mathrm{NIgM})$ is the earliest antibody isotype to be expressed during immune system development and is well represented in the circulation after birth, before the exposure to foreign antigens (9). Natural $\mathrm{IgG}$ repertoire (NIgG) is established within the first 2-4 years of life and it is highly homogenous among children and similar to the one expressed by healthy adults. Most of the NAbs in adult serum are of the $\operatorname{IgG}$ class $(5,9)$.

The most important role of NAbs is to provide key protection during the period between the onset of infection and the emergence of the adaptive immune response. Thus, these antibodies provide the initial defense against invading pathogens. Moreover, acquired immunity is not sufficient to protect an animal from the disease, such as influenza virus infection in the absence of NAbs in the body (10).

NAbs play a role in maintaining the homeostasis of the immune system, as well as regulating the immune response itself, through an idiotypic network whose significance was demonstrated in 1974 by Jerne (11). Idiotypes are the antigenic determinants in the variable region of antibodies which are recognized by anti-idiotypic antibodies. The idiotypic network comprises the interaction of both idiotypic and anti-idiotypicbearing antigen receptors on lymphocytes and idiotypic and anti-idiotypic antibodies. In case of an action of a sufficiently strong factor that disrupts the idiotypic network, the expansion of autoreactive Ig-producing clones can occur, and consequently, the 
pathological state of the organism in terms of the occurrence of autoimmune diseases, which is shown in mice $(12,13,14,15)$. The understanding of the relationship between vaccination and NAbs is further underlined by the fact that hyperimmunization can also act as a powerful autoreactivity-inducing factor $(16,17)$.

Another important role of NAbs has been identified in which immune complexes of antigens with natural antibodies activate complement and regulate T-cell mediated immunity, playing a role as endogenous adjuvant (18).

On the other hand, the secretion of NAbs of different isotypes is differently regulated and differently sensitive to the action of various factors. In a mouse model, selfantigen stimulation was shown to be sufficient to maintain NIgM levels, while foreign antigen stimulation (Streptococus pneumonie, influenza virus) was required to maintain NIgG and NIgA levels (19). It has also been shown that the change in NIgG depends on the diet, environmental factors and aging, but not on NIgM secretion (20). All this indicates that the cells that secrete different isotypes of NAbs react differently to external stimuli.

Given their polyreactive nature, NAbs have the ability to recognize various influenza virus epitopes. In a mouse model, it was shown that after NAbs binding to the influenza virus $(21,22)$, components of the complement system bind to formed immunocomplexes, thus neutralizing the virus (23), but not inducing virolysis. In addition, NIgM promotes pathogen recognition by antigen presenting cells (APCs) and influence the polarization of the immune response (Th1/Th2) (24). Moreover, NIgM is partially protective in antibody-deficient mice during the early phases of infection (23). Another important role of NIgM is to contribute to the formation of the acquired memory response. Specifically, it has been shown that for long-term memory response to influenza virus, mice require both complement and NAbs (25), suggesting that it would be especially important to examine this relationship during the immunization against influenza in humans.

Due to particularly high genetic variability of influenza virus, vaccination is advised annually to reduce the burden of the influenza disease. On the one hand, successful protection against influenza virus requires both types of host immunity, innate and acquired (26), and on the other hand, previous immunization with a seasonal vaccine affects the acquired immune response after subsequent vaccination the following season, through the phenomenon of crossreactivity between similar epitopes. For example, the analysis of human sera and ferrets' sera suggest that the specificity of pandemic H1N1 antibody responses can be shifted to epitopes near the HA receptor-binding domain after sequential infections with seasonal $\mathrm{H} 1 \mathrm{~N} 1$ and pandemic $\mathrm{H} 1 \mathrm{~N} 1$ viruses that share homology in this region (27). Considering all the aforementioned, we examined the effect of immunization with influenza vaccine on innate humoral immunity (NAbs pool) in humans. This effect is particularly important given that influenza vaccination is repeated once a year, which could possibly lead to a decrease in the overall antiviral response, in part because of the disruption of the healthy immune compartment by changing the production of NAbs (28). 
For this reason, we examine whether immunization induces changes in the NAbs composition in humans, as well as the trend of these changes. Addressing this issue may also be important because of the need to immunize humans against the SARS-CoV-2 virus and the impact that natural antibodies may have on it, especially since annual revaccination is one of the options being considered.

For NIgM analysis, we used a mouse monoclonal antibody (MoAb) Y7, specific to the idiotope located in the antigen binding site of human natural $\operatorname{IgM}(29)$. We have previously documented that human IgM molecules expressing Y7 idiotope exert NAb properties, i.e. binding to ssDNA, phospholypids, peptidoglycan and bacterial cells $(30,31)$.

Using MoAb Y7, we analyzed the effect of immunization against influenza on the pool of total and influenza-specific NIgM antibodies. The effect of immunization on the pool of total NIgG antibodies was assessed based on the binding of IgG antibodies to autoantigens (phosphatidyl serine (PtS), mouse laminin, ganglioside GM1, dsDNA). At the same time, we compared whether the vaccination status of patients (first-time immunized patients vs. patients immunized during previous seasons), as well as the type of vaccine administered (whole virus or split) could affect the expression of NAbs.

\section{Materials and methods}

\section{Study design and participants}

Collection of human sera samples for monitoring the immune response after immunization with trivalent influenza vaccines for 2003/2004 season was conducted between September and December 2003 in Serbia, in accordance with the Declaration of Helsinki and the International Conference on Harmonization-Good Clinical Practice. The study protocol was approved by an Institutional Review Board of the Institute of Virology, Vaccines and Sera "Torlak" (Belgrade, Serbia). Written informed consent was obtained from all participants. Healthy individuals (health care workers) 18-45 years old were enrolled. For those reporting previous influenza vaccination, documentation (Vaccination Card/record) was provided. None of the participants were sick or had a diagnosis of autoimmune disease; none of them participated in different studies and no woman was pregnant. The total duration of the study was one month. Serum samples from $\mathrm{n}=35$ participants were collected before (pre-vacc) and 30 days after (post-vacc) seasonal influenza vaccination. Paired serum samples were investigated at the Institute of Virology, Vaccines and Sera "Torlak" (Belgrade, Serbia).

Trivalent influenza vaccines for season 2003/2004, both whole virion and split, for the northern hemisphere contained the following strains as recommended by the World Health Organization (WHO) and the Committee for Medicinal Products for Human Use (CHMP) of the European Medicines Agency (EMA): A/New Caledonia/20/99(H1N1)like virus, A/Moscow/10/99(H3N2)-like virus and B/Hong Kong/330/2001-like virus. The first group of 14 participants was immunized with the whole virion influenza vaccine produced by the Institute Torlak, of which 5 patients had been immunized during previous 
years and 9 were vaccinated for the first time. Another group of 21 participants was immunized with the split vaccine, manufactured by Sanofi Pasteur, France, of which 8 patients had been immunized during previous years and 13 were vaccinated for the first time. Each participant was immunized i.m. with $45 \mu \mathrm{g} / \mathrm{dose}$ HA (15 mg HA of each virus strain). Blood samples were collected by venipuncture prior to and four weeks after immunization. Collected sera were complement depleted $\left(30 \mathrm{~min}\right.$ on $56^{\circ} \mathrm{C}$ ), aliquoted and stored at $-20^{\circ} \mathrm{C}$ until used for analysis. The sera were analyzed shortly after the collection of all samples.

\section{ELISA for detection influenza A H1N1 New Caledonia/20/99(H1N1) - specific IgG}

The intensity of the immune response after immunization of patients with influenza vaccine was evaluated by measuring influenza A H1N1 HA - specific IgG.

Whole virion A H1N1 New Caledonia/20/99 (antigen that was part of the vaccine composition for season 2003-2004) was adsorbed onto microtiter plates (Nunc MaxiSorp) at a concentration of $2.5 \mu \mathrm{g} / \mathrm{ml} \mathrm{HA}$ in phosphate buffered saline (PBS), $50 \mu \mathrm{l} / \mathrm{well}$, by overnight incubation at $4{ }^{\circ} \mathrm{C}$. The plates were then washed four times with PBS $(200 \mu \mathrm{l} /$ well), saturated with $1 \%$ bovine serum albumin (BSA)/PBS $(200 \mu \mathrm{l} /$ well) and incubated for $2 \mathrm{~h}$ at room temperature. The sera were diluted 1:500 in $0.05 \%$ Tween $20 / 1 \% \mathrm{BSA} / \mathrm{PBS}$ and $50 \mu \mathrm{l}$ were added to each well in duplicate. After incubation for 2 $\mathrm{h}$ at room temperature and a new cycle of washing, biotinilated anti-human IgG antibodies (Sigma-Aldrich, B3773) were added to wells according to manufacturer instructions. The color was developed by streptavidin peroxidase/OPD system. The reaction was stopped by adding $50 \mu 12 \mathrm{M} \mathrm{H}_{2} \mathrm{SO}_{4}$ and absorbance was monitored at 492 and 692 .

\section{Sandwich ELISA for detection of total natural IgM in patient sera}

Total NAbs were determined using the mouse MoAb Y7, specific for natural idiotope expressed on human antibodies. MoAb Y7 was produced in our laboratory by hybridoma technology, after the immunization of mice with a natural human IgM antibody (32). The specificity of this antibody was characterized in detail, and method for measuring the levels of antibodies carrying this natural idiotope previously established (33).

Briefly, a 96-well microtiter plate (MaxiSorp plates, Nunc) was coated with commercial goat anti-human IgM (Sigma-Aldrich, B1265), $50 \mu \mathrm{l} /$ well, at $4{ }^{\circ} \mathrm{C}$, overnight. After saturation with 1\% BSA/PBS, $(200 \mu \mathrm{l} /$ well, $1 \mathrm{~h}, \mathrm{RT})$ and washing, three times with $0.05 \%$ Tween 20/PBS (Sigma - Aldrich Co., St. Louis, Mo.) and once with PBS $(200 \mu \mathrm{l}$ per well), the wells were incubated with human sera at 1:500 dilution in $1 \% \mathrm{BSA} / \mathrm{PBS}$, at room temperature for $1 \mathrm{~h}$. After the next washing cycle, MoAb Y7 was added at a final concentration of $2.5 \mu \mathrm{g} / \mathrm{ml}$. The presence of the natural idiotope on captured sera IgM was detected by peroxidase-conjugated goat anti-mouse IgG (Sigma, B8774) and OPD system according to the manufacturer recommendation. 


\section{Competitive ELISA for detection of influenza A H1N1 New Caledonia 20/99 HA -specific natural IgM}

Since MoAb Y7 binds to idiotopes located in the antigen binding site on immunoglobulins, natural antibodies specific for influenza antigens were indirectly detected, using inhibitory ELISA. Two sets of plates were prepared for the purpose of inhibitory ELISA - one with and the other one without the inhibitor (MoAb Y7). The plates were prepared as described for the ELISA for detection of influenza A H1N1 specific IgG. After saturation, MoAb Y7, concentration of $200 \mathrm{ng} / \mathrm{ml}$, was mixed with human sera previously diluted in 1\% w/v BSA/PBS (final dilution of 1:3000) and preincubated for 2 hours at $37^{\circ} \mathrm{C}$. Concentration of $200 \mathrm{ng} / \mathrm{ml}$ was determined by ELISA, according to the binding curve of MoAb Y7 to the polyspecific natural human antibody IgMDJ which expresses Y7 idiotope (33). The mixture was next added to the first set of plates. Simultaneously, the same human sera in the same dilution but without MoAb Y7 were added to the second set of plates. Both sets of plates were then incubated for one hour at room temperature. For the detection of HA-specific IgM antibodies, biotinylated anti-human IgM antibody was used, prepared according to the manufacturer's instructions. ExtrAvidin ${ }^{\circledR}$ peroxidase/OPD was used as a detection system (SigmaAldrich). The difference in absorbance values obtained between the sera incubated with MoAb Y7 and those that were incubated without MoAb Y7 correlated to the relative levels of natural HA-specific IgM antibodies. Specifically, lower percent of inhibition indicated lower percent of HA-specific NIgM.

\section{ELISAs for detection of natural (autoantigen specific) IgG in patient sera}

In order to measure the level of different auto-antibodies in the sera of immunized people, we used the following autoantigens: phosphatidylserine (PtS), gangliosideGM $\mathrm{G}_{1}$, dsDNA and mouse laminin (all purchased from Sigma). PtS was dissolved in absolute ethanol at a concentration of $10 \mu \mathrm{g} / \mathrm{ml}$, adsorbed onto microtiter plate (PolySorp, Nunc) and kept at room temperature until ethanol evaporated. The plates were then blocked with $1 \% \mathrm{BSA} / \mathrm{PBS}$ and the sera (diluted 1:400 in $1 \% \mathrm{BSA} / \mathrm{PBS}$ ) were added $(50 \mu \mathrm{l} /$ well). The subsequent steps were performed using biotinylated anti-human IgG antibodies and the signal was developed as described previously.

Anti-dsDNA ELISA was performed by adsorbing poly-L-lysine (250 ng/ml in PBS) (Sigma) to each well of the MaxiSorp plate (Nunc) for 30 min at RT. The plate was then flicked and dsDNA $(10 \mu \mathrm{g} / \mathrm{ml})$ was added to the wells. For the purpose of detecting antidsDNA antibodies, we used dsDNA from calf thymus (Sigma-Aldrich, D1501). After that, the plate was incubated over night at $4{ }^{\circ} \mathrm{C}$. The plate was then fixed with $0.5 \%$ glutaraldehide/PBS for $15 \mathrm{~min}$, washed with PBS and blocked with $1 \%$ BSA/PBS. The sera for anti-dsDNA ELISA were diluted 1:400 in 1\% BSA/PBS and $50 \mu 1$ was added to wells. All subsequent steps were performed as described previously.

For the purpose of anti-laminin ELISA, laminin $(10 \mu \mathrm{g} / \mathrm{ml}$ in PBS) was adsorbed onto PolySorp microtiter plate (Nunc) and incubated overnight at $4{ }^{\circ} \mathrm{C}$. After blocking with $1 \% \mathrm{BSA} / \mathrm{PBS}$, the plate was washed with $0.05 \%$ Tween $20 / \mathrm{PBS}$, and sera were 
added at the dilution of 1:200. All subsequent steps were performed as described previously.

\section{Statistical Analysis}

The statistical analysis of the obtained data was performed using OriginPro Software and paired $t$-test. Absorbance values obtained for sera from participants prior to immunization were used as reference values. A $P$-value of 0.05 was considered as the limit of statistical significance.

\section{Results}

\section{Specific immune response to influenza vaccine}

The study was organized as an internal pilot study, in order to compare the newly developed whole virus vaccine produced at the Institute Torlak with a commercial vaccine, and regarding the actual pandemic situation we felt the obtained results were important both for health professionals and the general public.

In order to adequately analyze the effects of immunization on the pool of NAbs, we had to make sure that the influenza vaccine successfully triggered the specific immune response. Therefore, we evaluated the level of influenza A H1N1 New Caledonia specific IgG before and four weeks after immunization. We detected an increase in anti-H1N1 specific IgG, regardless of whether immunization was performed with a whole virus or split vaccine (Figure1). In addition, the immune response was triggered in both previously immunized patients and in patients for whom this was the first influenza vaccination (Figure 1). The relative change in the immune response was higher in patients who were not previously vaccinated, regardless of which type of vaccine was used.

\section{Total natural IgM after immunization}

Since NIgM is not as short-lived as the IgM that occurs at the beginning of immunization, we were able to analyze it in sera taken four weeks after immunization (Figure 2). By comparing the levels of NAbs in human sera before and after immunization with influenza vaccine, it was found that immunization did not lead to a change in NIgM antibody levels.

\section{Influenza- specific natural IgM}

The A H1N1 New Caledonia/20/99-specific NIgM antibodies were detected indirectly, by analyzing the degree of inhibition using natural idiotope-specific MoAb Y7- the greater the degree of inhibition of binding to A H1N1 antigen, the greater the amount of A H1N1-specific natural IgM antibodies in the patients' sera (Figure 3). Given that the analysis was performed four weeks post immunization, the potential contribution of the "adaptive" virus-specific IgM to the overall immune response was negligible, since the "adaptive" IgM is typically not detected so late post-immunization. Based on the detected inhibition of NIgM antibodies specific to the virion HA, it could be concluded that the immunization reduces the amount of specific NIgM. In subjects who were 
vaccinated for the first time, the decrease was not statistically significant, while in subjects who had been immunized in previous years, a statistically significant decrease was detected.
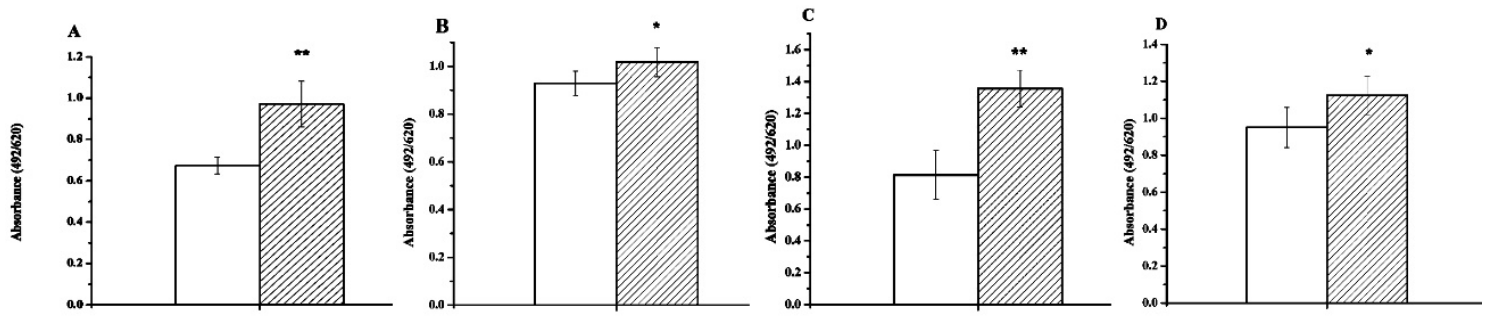

Figure 1. Changes in level of serum IgG antibodies against A H1N1 influenza virus strain after immunization with (A) whole virion vaccine, in patients who were not previously vaccinated; $(B)$ whole virion vaccine, in patients who were vaccinated in previous years; (C) split vaccine, in patients who were not previously vaccinated; (D) split vaccine, in patients who were vaccinated in previous years. Open columns represent IgG levels before immunization; columns with wide stripes represent IgG levels after immunization. Data are presented as means \pm SEM. ${ }^{*} p<0.5$, $* * \mathbf{p}<\mathbf{0 . 0 5}$.

Slika 1. Promena nivoa serumskih IgG antitela specifičnih za A H1N1 soj influence virusa kod pacijenata nakon imunizacije sa (A) celovirusnom vakcinom, ranije nisu vakcinisani; (B) celovirusnom vakcinom, ranije vakcinisani; (C) split vakcinom, ranije nisu vakcinisani; (D) split vakcinom, ranije vakcinisani. Beli stubići označavaju IgG nivo pre, a šrafirani nakon imunizacije. Podaci su prikazani kao srednja vrednost \pm SEM. ${ }^{*} \mathbf{p}<0.5, * * \mathbf{p}<0.05$.
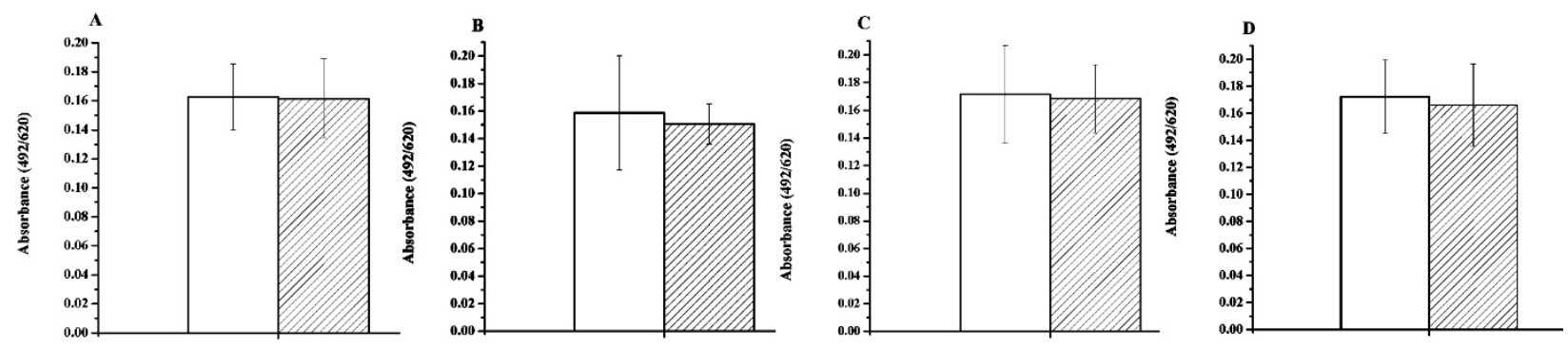

Figure 2. Changes in total serum NIgM antibody levels after immunization with (A) whole virion vaccine, in patients who were not previously vaccinated; (B) whole virion vaccine, in patients who were vaccinated in previous years; $(C)$ split vaccine, in patients who were not previously vaccinated; (D) split vaccine, in patients who were vaccinated in previous years. Open columns represent NIgM levels before immunization; columns with wide stripes represent NIgM levels after immunization. Data are presented as means \pm SEM.

Slika 2. Promene u nivou ukupnih serumskih NIgM antitela pacijenata nakon imunizacije sa (A) celovirusnom vakcinom, ranije nisu vakcinisani; (B) celovirusnom vakcinom, ranije vakcinisani; (C) split vakcinom, ranije nisu vakcinisani; (D) split vakcinom, ranije vakcinisani. Beli stubići označavaju NIgM nivo pre, a šrafirani nakon imunizacije. Podaci su prikazani kao srednja vrednost \pm SEM. 

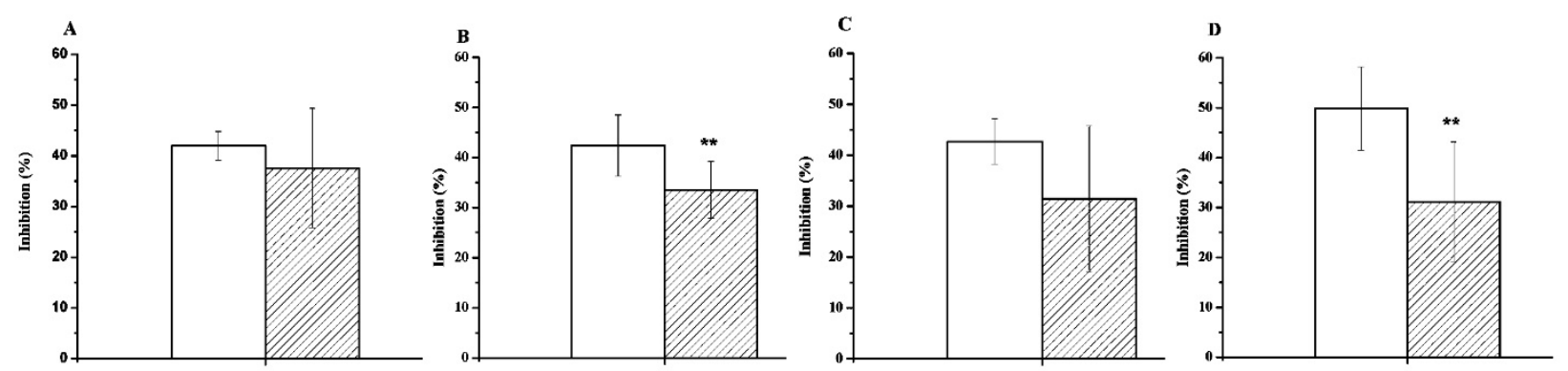

Figure 3: The percentage of inhibition of natural influenza A H1N1-specific IgM antibodies with natural idiotope-specific MoAb Y7 upon immunization with (A) whole virion vaccine, in patients who were not previously vaccinated; (B) whole virion vaccine, in patients who were vaccinated in previous years; (C) split vaccine, in patients who were not previously vaccinated; (D) split vaccine, in patients who were vaccinated in previous years. Open columns represent the percentage of inhibition before immunization; columns with wide stripes represent the percentage of inhibition after immunization. Data are presented as means \pm SEM. ${ }^{* *} \mathbf{p}<0.05$

Slika 3: Procenat inhibicije prirodnih influenza A H1N1-specifičnih IgM antitela pomoću Y7 monoklonskog antitela specifičnog za prirodni idiotop nakon imunizacije sa (A) celovirusnom vakcinom, pacijenti koji ranije nisu vakcinisani; (B) celovirusnom vakcinom, ranije vakcinisani pacijenti; (C) split vakcinom, pacijenti koji ranije nisu vakcinisani; (D) split vakcinom, ranije vakcinisani pacijenti. Beli stubići označavaju procenat inhibicije pre, a šrafirani nakon imunizacije. Podaci su prikazani kao srednja vrednost \pm SEM. ${ }^{* *} \mathbf{p}<0.05$

\section{Natural IgG after immunization}

We defined NIgG antibodies as antibodies to following self-antigens: phospholipids, gangliosides, mouse laminin, and dsDNA (Figure 4). The analysis of the presence of immunoglobulins of these specificities in the sera of subjects before and after immunization with influenza vaccine did not reveal a significant change in the levels of NIgG antibodies induced by the vaccination. The result was not dependent on the vaccination status of the subjects, the type of the vaccine received, or the nature of the antigen used in the test. 

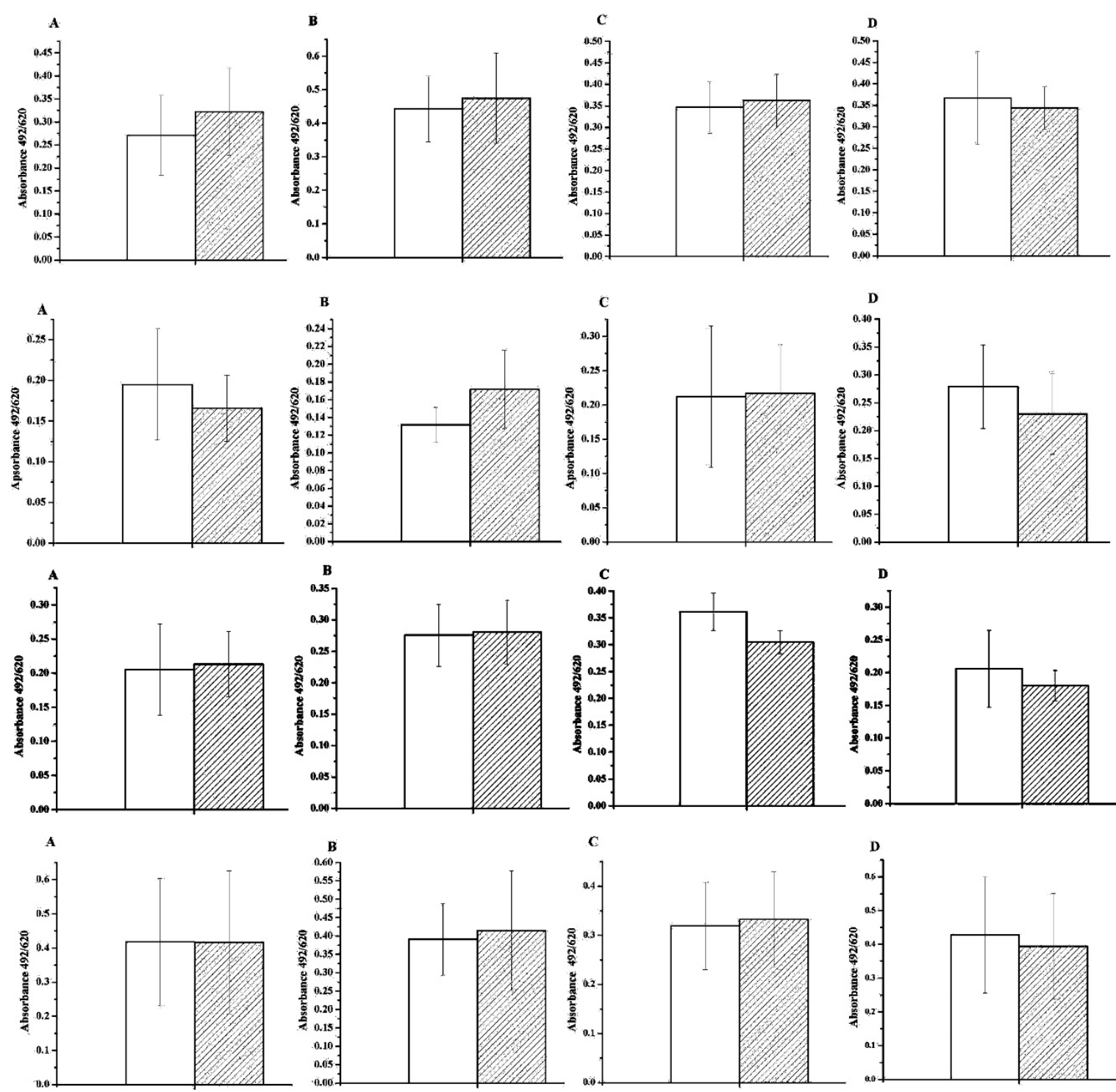

Figure 4: Changes in serum NIgG antibody levels specific to self-antigens, after immunization (A) with whole virion vaccine, in patients who were not previously vaccinated; (B) with whole virion vaccine, in patients who were vaccinated in previous years; (C) with split vaccine, in patients who were not previously vaccinated; (D) with split vaccine, in patients who were vaccinated in previous years. Open columns represent IgG levels before immunization; columns with wide stripes represent IgG levels after immunization. Row I: Anti- dsDNA IgG; row II: Anti- GM1 IgG; row III:

Anti-laminin IgG; row IV: Anti- PtS IgG. Data are presented as means \pm SEM.

Slika 4: Promene u nivou serumskih NIgG antitela specifičnih za sopstvene antigene nakon imunizacije pacijenata sa (A) celovirusnom vakcinom, ranije nisu vakcinisani;

(B) celovirusnom vakcinom, ranije vakcinisani; (C) split vakcinom, ranije nisu vakcinisani; (D) split vakcinom, ranije vakcinisani. Beli stubići označavaju NIgG nivo pre, a šrafirani nakon imunizacije. Red I: Anti- dsDNA IgG; red II: Anti- GM1 IgG; red III: Anti-laminin IgG; red IV: Anti- PtS IgG. Podaci su prikazani kao srednja vrednost \pm SEM. 


\section{Discussion}

By analyzing the levels of IgG specific for influenza A H1N1 New Caledonia virus, we confirmed that both influenza vaccines, whole virion and split, successfully triggered an immune response, which was a prerequisite to further conduct the analysis of NAbs during immunization. In addition, judging by the serum level of H1N1-specific antibodies, immunogenicity of the split and whole virion vaccines was similar. No matter what type of vaccine was used, the immune response, judging by the increase in serum level of H1N1-specific antibodies after vaccination, was more successful in people who had never been immunized against the flu (compared differences in anti-H1N1 IgG levels between corresponding pre- and post-vaccination samples) because what was measured was a relative change in antibody levels, which is more obvious in this group. The weaker immune response observed in people previously immunized with the seasonal influenza vaccine is already known in the literature as the Hoskins effect (antigenic sin) $(34,35)$. The Hoskins effect refers to the phenomenon that the immune system preferentially uses the immune memory acquired by a previous infection (or immunization) when encountering a new antigen that is very similar to the previous one. The immune system "trapped" by the first response is unable to achieve a potentially more efficient response during subsequent infections (immunizations), which can cause an inadequate immune response to a new strain of the virus. One must keep in mind that this phenomenon is related to both vaccination and infection, as the annual influenza burden was about $14 \%$ worldwide (36). Therefore, it is common practice to use laboratory animals to study innate immunity against influenza viruses. However, there are specific characteristics of the human immune response that cannot be analyzed using laboratory animals (37).

MoAb Y7 specific for human natural antibodies allowed us to distinguish natural from "adaptive" IgM antibodies and analyze the effect of immunization with different types of influenza vaccine on the total NIgM pool, as well as on NIgM specific for influenza antigens.

We found that immunization with the influenza vaccine did not induce a change in total NIgM antibodies, regardless of which type of vaccine was used (whole virion or split), as well as whether the subject had been previously immunized against influenza. This result was expected and desirable, given that a significant change in the amount of NAbs could lead to the imbalance of the idiotypic network and cause negative effects. Preservation of the total pool of NIgM is especially important because it has been shown that a decrease in these antibodies leads to enhanced production of pathogenic IgG autoantibodies and autoimmune disease (38). The primary role of NAbs is to maintain homeostasis of the immune system $(39,40)$. At the same time, it enables a delicate balance between the organism and commensal bacteria on one hand, and a strong immune response to pathogens, on the other hand. A strong stimulus, such as repeated immunizations or hyperimmunizations, can upset this balance, and thus lead to a pathological state. The obtained results showed that the functionality of the idiotypic network was preserved and that adequate immunization was provided. 
Our analysis detected a decrease in influenza-specific NIgM antibodies, especially in subjects who had been previously immunized with the influenza vaccine. At the same time, no change in total NIgM was observed after immunization, regardless of the type of vaccine used, and regardless of the vaccination status of the subjects. It is possible that the proportion of HA-specific NIgM antibodies in the total NIgM pool was so small that their change could not affect the total NIgM pool.

A change in antigen-specific NIgM can be considered an "imprint" left by immunization. Namely, in the groups of subjects who were immunized for the first time, the levels of these antibodies decreased, although without statistical significance. In the groups of subjects previously immunized with the influenza vaccine, subsequent immunizations led to a more pronounced decrease in the levels of these antibodies, i.e. the observed change became statistically significant. The reason for the decrease in HAspecific NIgM may be that these antibodies performed their "duty" to remove foreign antigens, in this case influenza virus antigens, with the period after immunization being too long for the levels to recover. Another possible explanation for the decrease in antigen-specific NIgM is that this pool was used to produce vaccine-induced highly specific antibodies. Similar conclusions were reached by the authors who noticed this phenomenon in animal models $(41,42)$. It has been shown that immunization of laboratory animals can induce an increase in the pool of NAbs, which are not pathological (autoimmune), but contribute to strengthening of the homeostasis of the immune system.

As most of the NAbs in adult serum are of the IgG class, we examined the change in NIgG after immunization. For this purpose, we analyzed natural autoantigen-specific IgG binding to phospholipids, gangliosides, laminin, and dsDNA. These antibodies differ from pathological antibodies of the same specificity in affinity and the amount in the patients' serum. Significant levels of anti-dsDNA antibodies are considered to be confirmatory in the diagnosis of SLE (43) and their serum concentration correlates with the severity of the disease. An increase in antibodies specific for phospholipids, including $\mathrm{PtS}$, is one of the characteristics of antiphospholipid syndrome (APS) (34). Antibodies to ganglioside GM1 (anti-GM1 antibodies) have been implicated in the pathogenesis of Guillain-Barré syndrome (GBS) (45), multifocal motor neuropathy (MMN) (46) and motor neuron disease (47). Anti-laminin IgG occurs in autoimmune-mediated reproductive failures, a skin pathology due to dermal-epidermal junction disorders (Mucous membrane pemphigoid). Mouse laminin used in this study is known to contain a carbohydrate epitope, known as the $\alpha$-Gal epitope, and antibodies recognising this epitope are represented by $1 \%$ of total natural antibodies (48). Influenza virus vaccines expressing $\alpha$-Gal epitopes are opsonized by anti-Gal immunoglobulin $G$, inducing effective uptake of the vaccine virus by APC and thereby stimulating influenza virusspecific T cells and eliciting a protective immune response (49), so possible fluctuations in its representation may be influential. Our results indicate no change in this respect.

As autoimmune diseases are probably caused and triggered by multiple environmental factors, one could theoretically speculate that the flu vaccine, as an external factor, might induce changes in that direction. However, low-affinity anti- 
dsDNA, anti-PtS IgG, anti-GM1 IgG and anti-laminin IgG antibodies are also part of the repertoire of natural IgG. Our results indicate that there was no change in the level of NIgG specific for the listed autoantigens, nor the appearance of pathological antibodies. It is especially important to note that even repeated immunization with influenza vaccine did not indicate changes in the direction of autoimmunity.

In literature (24), there are assumptions that autoimmune diseases could be caused by a disorder of the idiotypic regulatory network in which NAbs play a significant role. Our results did not indicate that there were changes in the pool of NAbs of either IgM or IgG isotypes that would lead to a pathological outcome. In other words, it was shown that the pool of NAbs remains stable during immunization with influenza vaccine. The type of antigen and the vaccine status of the patient did not affect the stability of the pool. The observed fluctuations of HA-specific NIgM are most likely necessary to establish a new equilibrium in the NAb pool after the entry of a foreign external factor, in this case the vaccine antigen.

In animal models, the relationship between natural and acquired antibodies can be described as follows (41). The levels of NAbs and induced Abs negatively correlate: in individuals with high levels of NAbs, antigen-specific antibodies develop less and vice versa. Because vaccination leads to the consumption of NAbs and in the first stage of developing a specific immune response, it may appear that there is a false tolerance to the vaccine antigen or a false suppression of the immune response. This means that the use of suboptimal doses and/or an inappropriate antigen formulation for vaccination can result in a significant reduction in the levels of protective (specific) NAbs without establishing an appropriate response.

The studies of the maintenance of NAb homeostasis and the fluctuations that occur during immunization, as well as the impact of the vaccine antigen used on this homeostasis are clearly very important, especially in certain vulnerable human populations. In the current situation of the SARS-CoV-2 virus pandemic, it would be particularly useful to analyze immune homeostasis after immunization of humans with the SARS-CoV-2 antigens, to determine whether these antigens have an effect on NAbs homeostasis, and whether repeated vaccinations each year may shift the pool of NAbs to a pathological direction.

\section{Acknowledgements}

The work presented in this paper was supported by the Institute of Virology, Vaccines and Sera "Torlak" funds and by the Ministry of Education, Science and Technological Development, Republic of Serbia No. 451-03-68/2020-14/200177. 


\section{References}

1. Reyneveld IJ, Savelkoul H, Parmentier H. Current Understanding of Natural Antibodies and Exploring the Possibilities of Modulation Using Veterinary Models. A Review. Front Immunol. doi: 10.3389/fimmu.2020.02139.

2. Besredka M. Les antihemolysines naturelles. Ann Inst Pasteur. 1901;15:758 -63.

3. Katz J, Parikh K. Intravenous Immunoglobulin: Medskape [Internet]. [updated Jul 05, 2018; cited 2021 Apr 03]. Available from: https://emedicine.medscape.com/article/210367-overview\#a3.

4. Zivkovic I, Minic R, Dimitrijevic L. Antimicrobial Immunoglobulin Prophylaxis and Therapy. In: Atta-ur-Rahman, editor. Frontiers in Clinical Drug Research - Anti Infectives 6. Bentham Science Publishers eBooks, Sharjah, United Arab Emirates; 2020; p. 165-205.

5. Avrameas S. Natural autoantibodies: from 'horror autotoxicus' to 'gnothi seauton'. Immunol Today. 1991;12(5):154-9.

6. Cohen IR. Autoantibody repertoires, natural biomarkers, and system controllers. Trends in Immunol. 2013;34(12):620-5.

7. Lacroix-Desmazes S, Mouthon L, Kaveri SV, Kazatchkine MD, Weksler ME. Stability of Natural Self-Reactive Antibody Repertoires During Aging. J Clin Immunol. 1999;19(1):26-34.

8. Lacroix-Desmazes S, Kaveri SV, Mouthon L, Ayouba A, Malanchere E, Coutinho A, Kazatchkine MD. Self-reactive antibodies natural autoantibodies in healthy individuals. J Immunol Methods. 1998;216(1-2):117-37.

9. Palma J, Tokarz-Deptuła B, Deptuła J, Deptuła W. Natural antibodies - facts known and unknown. Centr Eur J Immunol. 2018;43(4):466-75.

10. Baumgarth $\mathrm{N}$, Tung JW, Herzenberg LA.Inherent specificities in natural antibodies: a key to immune defense against pathogen invasion. Springer Semin Immunopathol. 2005;26(4):347-62.

11. Jerne NK. Towards a network theory of the immune system. Ann Immunol. (Inst. Pasteur) 1974;125C:373-89.

12. Adib M, Ragimbeau J, Avrameas S, Ternynck T. IgG autoantibody activity in normal mouse serum is controlled by IgM.J. Immunol. 1990;145(11):3807-13.

13. Zivkovic I, Petrusic V, Dimitrijevic R, Stojanovic M, Dimitrijevic Lj. Adjuvant dependence of APS pathology-related low-affinity antibodies during secondary immune response to tetanus toxoid in BALB/c mice. Immunol Res. 2013;56(1):143-9.

14. Petrusic V, Todorovic N, Zivkovic I, Dimitrijevic R, Muhandes L, Rajnpreht I, Dimitrijevic L. Autoantibody response and pregnancy-related pathology induced by combined LPS and tetanus toxoid hyperimmunization inBALB/c and C57BL/6 mice. Autoimmunity. 2014;48(2):87-99.

15. Petrusic V, Zivkovic I, Muhandes L, Dimitrijevic R, Stojanovic M, Dimitrijevic L. Infection-induced autoantibodies and pregnancy related pathology: an animal model. Reprod Fertil Dev. 2014;26(4):578-86.

16. Zivkovic I, Stojanovic M, Petrusic V, Inic-Kanada A, Dimitrijevic L. Induction of APS after TTd hyper-immunization has a different outcome in BALB/c and C57BL/6 mice. Am J Reprod Immunol. 2011;65:492-502.

17. Zivkovic I, Petrusic V, Stojanovic M, Inic-Kanada A, Stojicevic I, Dimitrijevic L. Induction of decreased fecundity by tetanus toxoid hyper-immunization in C57BL/6 mice depends on the applied adjuvant. Innate Immun. 2012;18(2):333-42. 
18. Stäger S, Alexander J, Kirby AC, Botto M, Rooijen NV, Smith DF, Brombacher F, Kaye PM. Natural antibodies and complement are endogenous adjuvants for vaccine-induced CD8+ T-cell responses. Nat Med. 2003;9(10):1287-92.

19. Haury M, Sundblad A, Grandien A, Barreau C, Coutihno A, Nobrega A. The repertoire of serum IgM in normal mice is largely independent of external antigenic contact. Eur $\mathrm{J}$ Immunol. 1997;27:1557-63.

20. Masmoudi H, Mota-Santos T, Huetz F, Coutinho A, Cazenave PA.All T15 Id-positive antibodies (but not the majority of VHT15+ antibodies) are produced by peritoneal CD5+ B lymphocytes. Int Immunol. 1990;2(6):515-23.

21. Baumgarth N, Herman OC, Jager GC, Brown LE, Herzenberg LA, Chen J. B-1 and B-2 Cell-derived Immunoglobulin $\mathrm{M}$ Antibodies Are Nonredundant Components of the Protective Response to Influenza Virus Infection, J Exp Med. 2000;192(2):271-80.

22. Harada Y, MuramatsuM, ShibataT, HonjoT, Kuroda K. Unmutated immunoglobulin M can protect mice from death by influenza virus infection. J Exp Med. 2003;197:1779-85.

23. Jayasekera JP, Moseman EA, Carroll MC. Natural antibody and complement mediate neutralization of influenza virus in the absence of prior immunity. J Virol. 2007;81(7):3487-94.

24. Kaveri S, Silverman G, Bayry J. Natural IgM in immune equilibrium and harnessing their therapeutic potential. J Immunol. 2012;188(3):939-45.

25. Gonzalez FS, Jayasekera JP, Carroll MC. Complement and natural antibody are required in the longterm memory response to influenza virus. Vaccine. 2008;(265):186-93.

26. Choi YS, Baumgarth N. Dual role for B-1a cells in immunity to infl uenza virus infection. J Exp Med. 2008;205(13):3053-64.

27. Yang L, Myers JL, Bostick DL, Sullivan CB, Madara J, Linderman SL, Liu Q, Carter DM, Wrammert J, Esposito S, Principi N, Plotkin JB, Ross TM, Ahmed R, Wilson PC, Hensley SE. Immune history shapes specificity of pandemic H1N1 influenza antibody responses. J Exp Med. 2013;210(8):1493-500.

28. Avrameas S, Ternynck T, Tsonis IA, Lymberi P. Naturally occurring B-cell autoreactivity: a critical overview. J Autoimmun. 2007;29:213-8.

29. Dimitrijevic LA, Stojanovic M, Ciric B, Radulovic M, Stojanovic R, Popovic Z, Inic-Kanada A, Zivkovic I. Expression of Y7 Cross-Reactive Idiotopeon Human IgM Molecules. Immunol Invest. 2004;33(1):1-14.

30. Petrusic V, Zivkovic I, Stojanovic M, Stojicevic I, Marinkovic E, Inic-Kanada A, Dimitrijevic L. Antigenic specificity and expression of a natural idiotope on human pentameric and hexameric IgM polymers. Immunol Res. 2011;51:97-107.

31. Dimitrijevic LA, Radulovic MI, Ciric BP, Petricevic MM, Inic AB, Nikolic DN, Apostolski S. Human monoclonal IgM DJ binds to ssDNA and human commensal bacteria. Hum Antibodies. 1999;9:37-45.

32. Radulovic, M., Ciric, B., Jurisic, A., Jankov, R., Apostolski, S., Zivancevic-Simonovic, S., Dimitrijevic, L. Expression of Y7 idiotope on IgM molecules from cord sera. In: Lukic M, MostaricaStojkovic M, Cuperlovic K, Colic M, editors. Immune Regulation in Health and Disease. London: Acad. Press Ltd; 1997; p. 205-11. 
33. Dimitrijevic L, Radulovic M, Ciric B, Odrljin T, Jankov RM, Marzari R. Immunochemical characterisation of a murinemonoclonal anti-idiotypic antibody. J Immunoassay. 1992;13:181-96.

34. Francis TJ. On the doctrine of original antigenic sin. Proc. Am. Philos. Soc. 1960;104(6):572-8.

35. Vatti A, Monsalve D, Pacheco Y, Chang C, Anaya JM, Gershwin ME. Original antigenic sin: A comprehensive review. J Autoimmun. 2017;83:12-21.

36. Lafond KE, Porter RM, Whaley MJ, Suizan Z, Ran Z, Aleem MA et al. Global Respiratory Hospitalizations-Influenza Proportion Positive (GRIPP) Working Group. Global burden of influenza-associated lower respiratory tract infections and hospitalizations among adults: A systematic review and meta-analysis. PLoS Med. 2021;1;18(3):e1003550.

37. Zschaler J, Schlorke D, Arnhold J. Differences in innate immune response between man and mouse. Crit Rev Immunol. 2014;34(5):433-54.

38. Grönwall C, Vas J, Silverman GJ. Protective roles of natural IgM antibodies. Front Immunol. 2012;3:66.

39. Avrameas S. Autopolyreactivity Confers a Holistic Role in the Immune System. Scand J Immunol. 2016;83(4):227-34.

40. Poletaev A, Osipenko L. General network of natural autoantibodies as immunological homunculus (Immunculus). Autoimmun Rev. 2003;2(5):264-71.

41. Sinyakov MS, Avtalion RR. Vaccines and natural antibodies: A link to be considered. Vaccine. 2009;27:1985-6.

42. Beinart D, Ren D, Pi C, Poulton S, Holzknecht ZE, Swanson C et al. Immunization enhances the natural antibody repertoire. EXCLI J. 2017;16:1018-30.

43. Sabbaga J, Pankewycz O, Lufft V, Schwartz R, Madaio M. Cross-reactivity Distinguishes Serum and Nephritogenic Anti-DNA Antibodies in Human Lupus from their Natural Counterparts in Normal Serum. J Autoimmun. 1990;3(2):215-35.

44. McIntyre JA, Wagenknecht DR, Faulk WP. Antiphospholipid antibodies: discovery, definitions, detection and disease. Prog Lipid Res. 2003;42(3):176-237.

45. Lardone RD, Yuki N, Odaka M, Daniotti JL, Irazoqui FJ, Nores GA. Anti-GM1 IgG antibodies in Guillain-Barré syndrome: fine specificity is associated with disease severity. J Neurol Neurosurg Psychiatry. 2010;81(6):629-33.

46. Cats EA, Jacobs BC, Yuki N, Tio-Gillen AP, Piepers S, Franssen H et al. Multifocal motor neuropathy: association of anti-GM1 IgM antibodies with clinical features. Neurology 2010;75(22):1961-7.

47. van Schaik IN, Bossuyt PM, Brand A, Vermeulen M. Diagnostic value of GM1 antibodies in motor neuron disorders and neuropathies: a meta-analysis. Neurology 1995;45(8):1570-7.

48. Galili U. Anti-Gal: an abundant human natural antibody of multiple pathogeneses and clinical benefits. Immunology. 2013;140(1):1-11.

49. Abdel-Motal UM, Guay HM, Wigglesworth K, Welsh RM, Galili U. Increased immunogenicity of influenza virus vaccine by anti-Gal mediated targeting to antigen pre-senting cells. J Virol. 2007;81:9131-41. 


\section{Efekat imunizacije vakcinom protiv gripa na prirodna antitela}

\section{Irena Živković *1, Lina Muhandes ${ }^{1}$, Vladimir Petrušić1, Rajna Minić1, Ljiljana Dimitrijević ${ }^{1}$}

${ }^{1}$ Institut za virusologiju, vakcine i serume- Torlak, 458 Vojvode Stepe, 11000 Beograd, Srbija

*Autor za korespodenciju: Irena Živković, E-mail: izivkovic@torlak.rs

\section{Kratak sadržaj}

Prirodna, polireaktivna i slabo afinitetna antitela igraju važnu ulogu ne samo u neposrednoj odbrani od patogena, već i u oblikovanju stečenog imunskog odgovora. S druge strane, indukcija visoko afinitetnih, antigen - specifičnih antitela, može uticati na ravnotežu prirodnih antitela i time dovesti do autoimunskih bolesti. U ovoj studiji analizirali smo da li imunizacija ljudi split ili celovirusnom vakcinom protiv gripa može dovesti do promena u IgM i IgG pulu prirodnih antitela. Za analizu su korišćeni "in-house" razvijeni ELISA testovi. Ispitanici su podeljeni prema vakcinalnom statusu na one koji su prethodnih godina bili imunizovani vakcinom protiv gripa $i$ one koji su prvi put imunizovani. Pokazano je da imunizacijom nije narušen ukupan pul prirodnih antitela ni u jednoj grupi i da je došlo do određenih fluktuacija u nivoima prirodnih antitela kako bi se održala homeostaza imunskog sistema.

Ključne reči: prirodna antitela, imunizacija, imunološka homeostaza 